\title{
China's Quest for World-Class Teachers: A Rational Model of National Initiatives and Institutional Transformations
}

(Abstract)

\author{
Dr. LI Jun \\ Education Policy Unit \\ Faculty of Education, the University of Hong Kong
}

Teacher education has been undergoing significant transformations worldwide in recent decades, and China has made continuous efforts in its quest for world-class teachers. This paper aims at a comprehensive investigation of the complex policy process in China's national initiatives to nurture a world-class teaching force, with qualitative findings from a case study. It focuses on policy initiatives in China's unique sociocultural context, system transformations and developmental challenges from a rational prospective. Meanwhile, the challenges of institutional change and the limitations to change are examined within two frames - the contextually less amenable to change and the institutionally remediable. Policy implications for teacher education reform in the future are illustrated within these two frames. Lastly, this paper concludes that along with its rising status, in terms of excellence in educational performance and students' academic achievement as shown in PISA 2009, China provides an alternative model for building a world-class teaching force and may have multiple implications for the international community in an age of globalization.

Keywords: Teacher education reform; implementation; institutional transformation; rational model; China. 


\title{
China's Quest for World-Class Teachers: A Rational Model of National Initiatives and Institutional Transformations
}

\author{
Dr. LI Jun \\ Education Policy Unit \\ Faculty of Education, the University of Hong Kong
}

The record-breaking performance of Shanghai students in all domains of the recent PISA results (OECD, 2010) has astonished the globe, though this achievement needs more prudent investigation. Worldwide attention has been paid to how Chinese learners are able to attain such a highly competitive edge over top students from the rest of the world. One of the key factors, as identified by Liu Jinghai, a well-known principal in Shanghai, rightly pointed out that teachers are the key to the success of Chinese students and education as well (OECD, 2012).

China has tried to nurture world-class teachers for over a century, and the recent PISA results of Shanghai students confirmed the outcomes of such national endeavors. Although there has been a plethora of studies on Chinese teachers and teacher education reform, the impact of national policies on teacher education institutions (TEIs) still remain a mystery. How have TEIs reshaped their institutional missions and strategies to respond to the national reform? What institutional transformations have taken place? And what challenges are arising from this process? Adopting a case study approach, this study aims at using a rational perspective to investigate the institutional transformations resulting from teacher education initiatives in China.

\section{THE SOCIO-HISTORICAL AND GLOBAL CONTEXT}

The modern system of teacher education was established in China for political purposes to serve national survival and revival and to catch up with Western powers in the late $19^{\text {th }}$ century. This post-colonial catch-up mentality has continued over a century, with four stages of development under various historical contexts: the first stage of establishment (1897-1911), the second stage of institutionalization (1912-1949), the third stage of re-institutionalization (1949-1993) and the most recent stage of professionalization (1993-present) (Li, 2012).

A fundamental characteristic of the four stages of teacher education has been China's quest for a world-class teaching force that could serve its self-strengthening against Western imperialism and colonialism in the past and its modernization in the new context of globalization from the late 1970s. Since its door was opened to the world in 1978, China has had to face dual challenges to teacher education, arising from its post-colonial circumstances and ever intensifying trends of globalization. On the one hand, alternative pathways have been explored to raise the overall quality of the teaching force up to world-class standards and changes have been made to the system to meet global demands, i.e., a redefining of the multiple identities of teachers. On the other hand, the new model of teacher education has been built upon China's own traditions as a country that has a long history of education. In other words, China has been seeking a form of teacher professionalism that balances the global and the local (Li, 2012; 2013, Feb. 7).

\section{KEY NATIONAL INITIATIVES}

To quest for world-class teachers who are highly qualified, first-rate in teaching 
competency (The State Council, 2012, Aug. 20), China has launched persistent national initiatives for the institutional changes of its teacher education system since the early 1990s (see Table 1).

Table 1: Policy Initiatives for Teacher Education Reform (1993-2012)

\begin{tabular}{|c|c|}
\hline Policy Documents & Dates \\
\hline $\begin{array}{l}\text { The Guidelines for the Reform and Development of Education in China by the CPCCC \& } \\
\text { the State Council }\end{array}$ & Feb. 13, 1993 \\
\hline $\begin{array}{l}\text { The Law of Teachers of the People's Republic of China by the Standing Commission of the } \\
\text { National People's Congress }\end{array}$ & Oct. 31,1993 \\
\hline The Ordinance of Teacher Qualification by the State Council & Dec. 12,1995 \\
\hline $\begin{array}{l}\text { The Ninth Five-Year Plan for China's Educational Development and the Development } \\
\text { Outline by } 2010 \text { by the State Commission of Education (SCE) }\end{array}$ & Apr. 10, 1996 \\
\hline The Opinion on the Reform and Development of Teacher Education by the SCE & Dec. 5,1996 \\
\hline $\begin{array}{l}\text { The Action Plan for Educational Revitalization Facing the } 21 \text { st Century by the Ministry of } \\
\text { Education (MOE) }\end{array}$ & Dec. 24,1998 \\
\hline The Opinion on Adjusting the Structure of TEIs by the MOE & Mar. 16, 1999 \\
\hline $\begin{array}{l}\text { The CPCCC and State Council's Decision on the Deepening of Educational Reform and the } \\
\text { Full Promotion of Quality Education by the CPCCC and the State Council }\end{array}$ & Jun. 13, 1999 \\
\hline The Decision on the Reform and Development of Basic Education by the State Council & May 29, 2001 \\
\hline The Guidelines for Basic Education Curriculum Reform by MOE & Jun. 7, 2001 \\
\hline The Tenth Five-year National Plan for Education by the MOE & Jul. 2001 \\
\hline $\begin{array}{l}\text { The Opinion on the Reform and Development of Teacher Education during the Tenth Five- } \\
\text { year National Plan by the MOE }\end{array}$ & Feb. 6, 2002 \\
\hline The Rejuvenation Action Plan for Education 2003-2007 by MOE & Feb. 10, 2004 \\
\hline $\begin{array}{l}\text { Guidelines for Mid-and Long-term Educational Reform and Development 2010-2020 by the } \\
\text { State Council }\end{array}$ & May 5, 2010 \\
\hline $\begin{array}{l}\text { The National Training Project for Elementary and Secondary School Teachers (Guopei } \\
\text { Jihua) by the MOE }\end{array}$ & Jun. 11, 2010 \\
\hline The Curricular Standards for Teacher Education by the MOE & Oct 8,2011 \\
\hline The Opinion on the Enhancement of the Teaching Workforce by the State Council & Aug. 20, 2012 \\
\hline
\end{tabular}

Central to these policy mandates is the improvement of the overall quality of basic education through a variety of policy actions. These include a rational approach to improving the professionalism of the teaching workforce, and the reform of TEIs. The above fourteen government policy documents articulate the rationale, policy problems, major policy goals and guidelines for nationwide teacher education reform since 1993.

Chinese policymakers have a strong belief in certain rational assumptions about human behavior, and thus the following equation may be used to sum up these assumptions: $\mathrm{TE} \rightarrow \mathrm{CT} \rightarrow \mathrm{QE} / \mathrm{SA} \rightarrow \mathrm{QL} \rightarrow \mathrm{MD} / \mathrm{EG} \rightarrow \mathrm{NAC}$. This simplified equation expresses the views of Chinese leaders that a better system for teacher education (TE) prepares more competent teachers (CT), better prepared teachers improve the quality of education and student achievement (QE/SA), higher educational quality and student achievement result in the 
higher quality of the labor force (QL), the higher quality of the labor force tremendously benefits the country's modernization and economic growth (MD/EG) and eventually leads to China's national achievement and competitiveness (NAC). Based on these assumptions, teacher education is seen as the first and foremost domain for reform.

In addition to key national initiatives for teacher education, the Chinese government launched the expansion of higher education since the mid-1990s (Hayhoe, Li, Lin \& Zha, 2011), and the New Curriculum Reform for Basic Education in 1999. Both movements of reform have brought many challenges to TEIs. They pushed TEIs to focus on the unprecedented expansion in student enrollment within a few years, which placed high pressure on teaching staff and campus facilities. In the expansion process, new programs and departments were set up while TEIs were undergoing systematic restructuring; thus higher education expansion has had a notable impact on the system of teacher education. The New Curriculum System for Basic Education is viewed widely as the core of current reform and a key to promoting school excellence. As a result, it too creates high pressure on the reform of teacher education, as it requires teachers, including prospective teachers and in-service teachers, to upgrade their professional skills and knowledge across a broad area. It has also challenged the national initiatives of teacher education in terms of setting higher standards and requirements for teachers. These national policies alternately reinforced each other in some areas and worked against each other in other areas.

\section{EXISTING ANALYSES}

There are a number of existing analyses of teacher education reform in China, which provide initial insights into various dimensions of its changes. Paine (1992) observed that China has introduced technical strategies to strengthen its teacher education system to attract better students, to enhance the curriculum and teaching, and to establish high standards by looking into two competing discourses, modernizing and nationalizing perspectives. Following Paine's accounts, Shen (1994) focused on teacher education reform in China under the national drive toward modernization and a market-based economy. Li (1999) studied the recent reform by looking into the establishment of a nationwide network of teacher preparation and professional development centers, the launching of nationwide efforts at upgrading the qualifications of in-service teachers, the building of nationwide respect for teachers and consequent improvement in the treatment of teachers. Lin and Xun (2001) outlined new trends in teacher education development. Meanwhile, Ashmore and Cao (1997) acknowledged that the large number of unqualified teachers and low level normal schools created obstacles for teacher education reform.

There are a number of other policy analyses that address China's reform of teacher education at the local level. Although the teacher education system was largely restored in the 1980s following the chaos of the Cultural Revolution, Ma (2000) pointed out that current TEIs are managed with little consideration by various governmental offices at different levels, and limited resources for teacher education are not efficiently allocated and utilized.

Some researchers are not satisfied with these analyses but instead reflect on their own experiments and point to new directions in the efforts of teacher education reform. In her experiment on combining teaching with research for the New Curriculum Reform for Basic Education, Ye (2000) concluded that the combination of theoretical research and practical research in school reform benefits the professional development of a new type of teacher in many ways. On the other hand, Li (2010) demonstrated how three different "logics" - that of 
institutional strategies, economic demand and state political initiatives have driven the developmental model of TEIs in China, with a detailed comparison of three leading universities for teachers. Foreign models of teacher education system also provide China with valuable experiences (Hayhoe, 2002; Hayhoe \& Li, 2010; Li, 2012; Zhu, 2001).

In addition, Dooley (2001) offered a case study conducted in Shanghai, vividly describing how "obedient students" are mechanically trained by teachers who received professional education from independent, closed and narrowly specified TEIs. Along similar lines, four problems of teacher education were identified by Leung and Xu (2000). These problems are the identity crisis, the mismatch between teacher supply and demand, the incongruence between teacher preparation and classroom realities, and the poor appeal of teaching as a career.

The mentioned studies provides valuable information about the background of teacher education reform in China and some core issues, but they have never focused on the key process, i.e., the micro implementation, of China's national quest for world-class teachers. Empirical studies on institutional change brought about by recent national initiatives are particularly missing. This paper will try to address that gap. But first I will outline the rational framework that is being adopted and the methodological considerations that shape this effort.

\section{THE RATIONAL FRAMEWORK}

Public policy is commonly accepted as a purposeful course of action advanced or authorized by higher institutional levels of the policy system in pursuit of influencing lower levels or units of the system (Fowler, 2013). From this point of view, it holds at least one basic assumption, i.e., public policy is a rational collective behavior aiming to achieve proposed policy goals. Based on this assumption, the rational framework stands out as suitable to understand China's complex process of teacher education reform.

A cardinal assumption of the rational framework is that human behavior is purposely rational and that a policy process is thought of "as purposive, goal-directed activity" by a rational unified player (Allison \& Zelikow, 1999, p. 17). Further, a means-ends driven and goal directed principle is practiced by policy players and is evident throughout the policy process: "first the ends are isolated, then the means to achieve them are sought" (Lindblom, 1959 , p. 81). To achieve the policy ends through chosen means, a policy process usually starts its linear journey with first identifying the substantial policy problems. Then, alternative strategies are considered, evaluated and compared. Optimal strategies that are likely to be most efficient are finally chosen to solve the identified policy problems. In addition, Jenkins (1978) assumed that policy emerges via a logical path. This assumption may help explain the policy action expressed in China's national initiatives and their impact on TEIs since the early 1990s.

The rational framework has been selected as it matches well the purpose of this study and the reality of the sociopolitical context of China. In addition, it can help, with its emphasis on logic, to order and simplify the complexity of the policy process, identify what is significant, and direct inquiry and research.

\section{METHODOLOGICAL CONSIDERATIONS}

Since this study looks for in-depth descriptive interpretations of the sophisticated policy process of China's national reform of teacher education, it has adopted the theoretical 
sampling technique with a typical-case approach. The site of the case was limited to a medium-sized city in a mid-level-developed province in inland China. The gross regional product (GRP) and per capita net income of households were used by this study to measure the socioeconomic development of a region. Similarly, the case was carefully limited to one institution which is typical of provincial normal universities in medium developed provinces. Based on the above criteria, the province of Yangtze (a pseudonym) was selected as the site and Yangtze Normal University (YNU) as the case for this study.

YNU is situated in a busy inland metropolitan area in east China. Though YNU has been a national comprehensive university in its early history, it was reconstructed as a key provincial teacher education institution in the early 1950s. By 2012, it had 16 schools on three urban campuses with a faculty-student ratio of one to twenty four. It offered around 70 undergraduate programs and had a total of 22,000 full-time students, with $36.6 \%$ receiving teacher education. YNU's College of Educational Science (CES) was formed in 2000, aiming to prepare educators, psychologists, educational administrators and researchers. With 70 faculty members, the CES has a total of 900 full-time undergraduate students in six programs of teacher education, plus 600 graduate students.

The theoretical sampling technique was also used for identifying individual interviewees. A total of 17 interviewees were successfully recruited from YNU's CES, with 11 leaders or administrators and six faculty members. In addition, documentation and archival records were collected as additional data sources for triangulation. Meanwhile, ethical codes and consent forms were used consistently throughout the study. The completed interview process involved a combination of three basic approaches for open-ended interviews, i.e., the informal conversational interview, the general interview guide, and the standardized open-ended interview (Pattern, 2002), as best fitted the situation. The field work was mainly finished in 2005 but efforts were made to follow on subsequent developments up to 2012. Data were triangulated with other data sources such as documents collected on-site, and verified by accounts of various participants. Data analysis with coding was made shortly after the transcripts were complete. The master codes included several key variables and their corresponding subunits of analysis, and the second level of codes was based on Bogdan and Biklen's ten coding categories (1998, pp. 172-177).

\section{INSTITUTIONAL TRANSFORMATIONS}

\section{Linear Delivery of Policy Flow}

It is common that Chinese TEIs are under the supervision of the MOE or the Provincial Bureau of Education (PBE). Generally, national policies are linearly channeled from the $\mathrm{MOE} / \mathrm{PBE}$ to TEIs in two ways. Oftentimes, before a national policy of education is formally publicized, university leaders will be summoned for a special meeting to the MOE/PBE. After that, the university leaders will plan how to implement the policy on campus based on the policy document and its requirements. Sometimes a national policy is delivered via the official delivery system from the MOE to universities directly or via the PBE indirectly. In this process, the PBE serves as a conveyor or a buffer agency.

As a provincial key normal university, YNU usually receives national policies from the Yangtze PBE. Once national policies are officially passed down, YNU would hold special working meetings to implement them, especially major policies. For example, on Sept. 18, 2004, YNU held the Third Working Meeting on Teaching, in order to implement the requirements of The Rejuvenation Action Plan for Education 2003-2007 by the MOE (2004, 
February 10). The implementation goals and strategies were put into place soon after these working meetings. As shown in Figure 1.1, the policy flow at YNU for the implementation of the national policy was top-down and linear. This was taken as a rational, efficient and systematic way to deliver national initiatives to an individual institution.

Figure 1: The Policy Flow

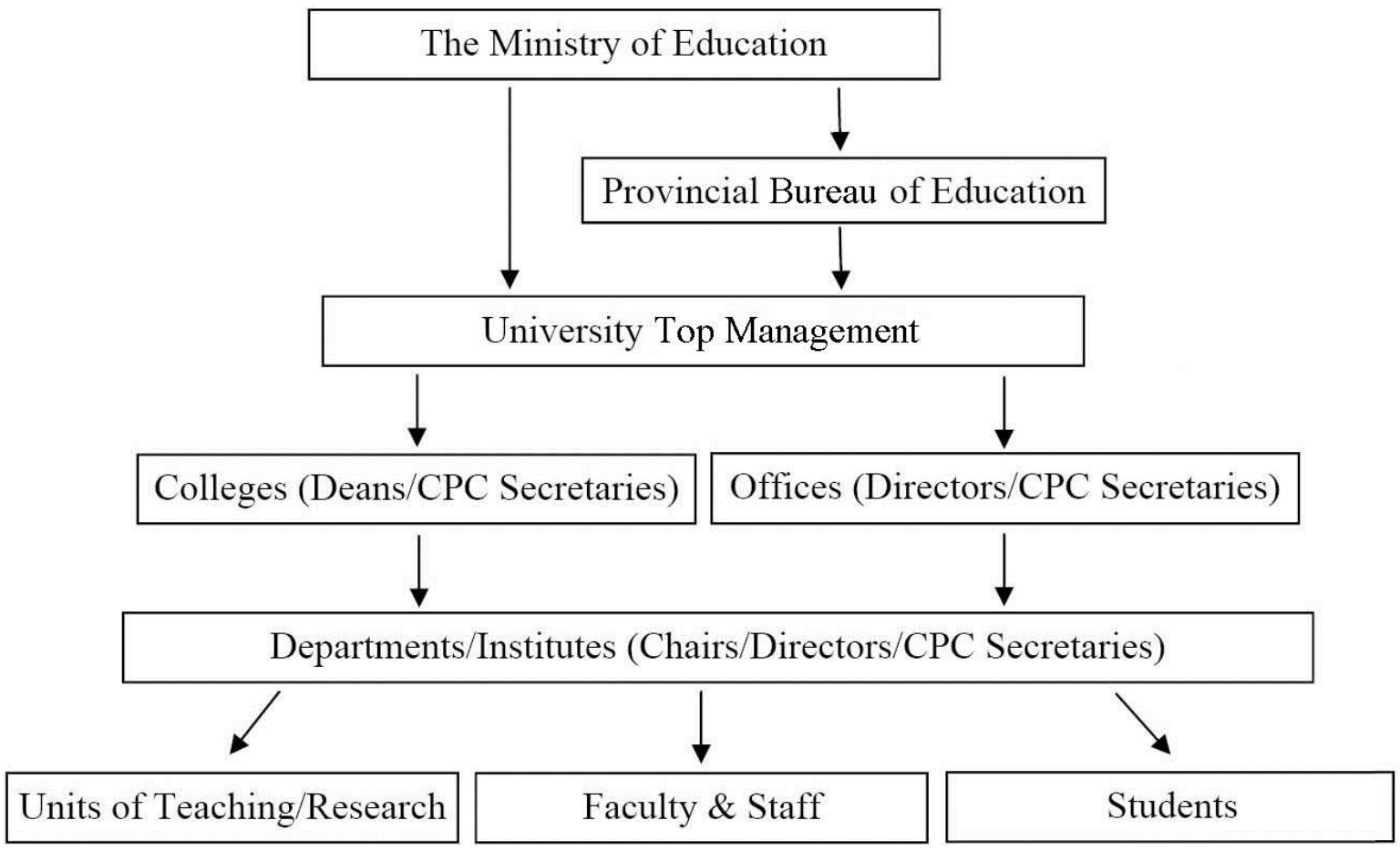

Communication is a key process by which policy goals and strategies are mapped out for implementers and participants. Like many other TEIs, YNU routinely adopts policy delivery through regular official propaganda, chuanda, as a form of communication for the implementation of national policies, which literally means passing the message on and down. One of its major forms is holding special meetings or seminars such as officially organized political study sessions, zhengzhi xuexi. According to most participants the political study process has never been interrupted at YNU. When interviewees were asked about the specific communication means employed to implement the national reform of teacher education, two deans responded that it was the most popular channel through which the national policy was disseminated. Department chair Caifei ${ }^{1}$ noted that it served as the major source for his faculty to learn about the national reform of teacher education. For dean Enwei, it is the mandatory form that everybody has to participate in.

\section{The New Institutional Mission}

YNU's original mission before the 1990s was very typical and general, just like that of any other university in China, as stated below in one of YNU's official documents published in October 1983:

Yangtze Normal University is a provincial key normal university with a long history,

\footnotetext{
${ }^{1}$ Pseudonyms have been used for all participants throughout this paper.
} 
providing comparatively complete programs in science and liberal arts for training teachers. It aims to produce more qualified talents for socialist construction and contribute to the socialist country.

The university's top management and implementers met from July 30th to August $2^{\text {nd }}$, 2003, to plan for the future development of YNU. Debates took place on topics such as what type of university, fully comprehensive or focused on teacher education, should YNU become, and how to construct one or the other. In April 2005, the university's Strategic Plan for the Eleventh Five-year Plan and the Year of 2015 reshaped its mission as follows:

We will strive to build up a comprehensive teaching and research university primarily featured with teacher education, to become a key base for producing high-level talents in research and technology innovation in the province and, to contribute to the revitalization of Yangtze province through science and education.

The new mission clearly keeps its original statement that the university aimed to be a provincial key teaching institution and a research base for teacher education and is evolving toward a comprehensive university featuring teacher education.

In addition, as professor Peishi and department chair Beihua have observed, YNU has taken substantial steps to establish its CES with a new vision by promoting teacher education and optimizing resources for teacher education, improving the quality of the teacher workforce and promoting teacher professionalization, building a prestigious college of teacher education in the province and becoming one of the bases for teacher education in the country. After the CES was established, as dean Hengtang suggested, teacher education programs at YNU retained their current numbers, but the teaching quality of the programs was considerably enhanced, and so was the status of teacher education at YNU.

\section{Institutional Focuses and Strategies}

To effectively implement the national initiatives of teacher education reform, YNU tried to strictly follow them which urged TEIs to "build up a highly qualified teacher workforce" by redoubling their efforts toward the structural adjustment of teacher education programs, continuously enforcing the reform on training models and curricular systems, and improving training quality (The MOE, 2002, February 6). The strategies YNU adopted encompassed a wide range of efforts.

\section{Enhancing teaching for prospective teachers}

In order to implement the national policies of teacher education reform and to enhance the quality of teaching at YNU, its leaders held three university-wide working meetings on teaching in 1996, 1999 and 2004, respectively. At the Third Meeting on Teaching, YNU's President warned that the quality and quantity of the faculty of YNU did not meet the needs of the university's development and the goals of the national reform. In the same year, The Opinions on Deepening Teaching Reform, Speeding up Teaching Innovation, and Improving Teaching Quality in Yangtze Normal University was formally published. In this document, the leaders reviewed and assessed the challenges YNU faced in improving teaching quality, and viewed the problematic teaching quality in the programs of various departments as the bottleneck restricting the development of YNU. They proposed various strategies for the implementation of the national reform in order to build a stronger and larger faculty for the university in the near term. These strategies included starting new degree programs, systematically transforming from the academic-year system, which the university had long used, to a new credit system, strengthening the teaching workforce and its management, upgrading teaching facilities and improving the learning environment. 


\section{Starting new degree programs}

Since June 1994, YNU has offered new programs for undergraduates and graduates, in addition to its traditional ones. Since 2001 YNU has provided undergraduate students such courses as modern educational technologies to address new challenges in education from information technologies. In addition, many new graduate programs have been offered since 1998. These programs include Master's programs in aesthetics, modern Chinese literature, general theory of education, analytical chemistry, physical chemistry, applied mathematics, etc. Doctoral programs were offered as well, such as those in ancient Chinese history, ancient Chinese literature, ecology, organic chemistry, etc.

Since 1999, YNU has been accredited by the MOE to confer the Educational Master's Degree in Subject Teaching (M.Ed.), which covers three graduate programs: administration of education, subject teaching of chemistry, and subject teaching of the Chinese language. The newly started Master's degree programs showed that YNU employed substantial strategies in implementing the national reform of teacher education to fulfill its goal of structural adjustment of teacher education programs. By 2012, around 600 students were enrolled in various postgraduate programs in the CES.

\section{Strengthening the teaching workforce and management}

YNU has tightened the management process for ensuring its high quality of education, and adopted new quantifiable indicators to measure teachers' job performance. Some interviewees were proud of these measures because YNU was among the few pioneering universities that made this change in China. These measures, routinely undertaken at the end of each semester, evaluated teachers' job performance in classroom teaching and research by a list of quantifiable indicators. For example, the measures on teachers' classroom performance covered a wide range of indicators from teaching aims, to teaching attitudes and preparation, to teaching methods and teaching effectiveness. The assessment forms were filled out by students and administrators.

The university leaders reasoned that these quantifiable measures would serve the goal of strengthening the teaching workforce and its management. They were taken as rational steps to set high standards for the assurance of teaching quality. These strategies and actions, especially the recently enforced quantifiable measures for assessing teachers' job performance, however, were viewed by faculty participants in the study as instruments being used by the leaders to oppress them. They were pressured against their will to respond to these instrumental measures initiated by those in power, along the lines noted by Aronowitz and Giroux in their critical discussion of this issue (1993, p. 50). Professor Ningdong reported that the real purposes of these quantifiable measures were solely to determine if a faculty member could be promoted or not in the near future. For example, the university set $85 \%$ as the eligible score for the promotion to full professor. If a faculty member who was applying for the position of full professor only earned a score of $84 \%$, his or her application would be rejected no matter how excellent the job performance was in other areas.

\section{Enhancing teacher education as YNU's key feature}

As a normal university, YNU took advantage of its characteristic teacher education programs to meet the requirements of the implementation of the national reform. After the credit system was adopted, a big change was offered to students in terms of taking teacher education courses. The ratio of teacher education courses required of undergraduate students jumped from $6 \%$ up to $16 \%$ in the total required credits for a Bachelor's degree. At YNU, this was a key step in enhancing teacher education and teacher professionalism through the 
implementation of the national reform.

Like any other normal university in China, YNU provides required core courses in teacher education in three areas: a general introduction to education, psychological studies and subject teaching pedagogy. The teaching contents are usually edited by senior scholars in the field of education. Now the university upgraded the contents and requirements of teacher education courses. For example, the General Introduction to Education, a course intended for all undergraduate students in teacher education programs, used to consist of four major components adopted from Soviet educator Kairov's model: basic theories, pedagogy, moral education and school administration. Today those four components have been replaced with new ones such as the relationship of teachers and students, society and education, modern learning theories, etc. To the original trio mentioned above YNU added a fourth required core course: Educational Technologies. This was a significant gesture aimed at enhancing teacher education in response to the challenges from information technologies.

In addition to making available more choices of teacher education courses for prospective teachers, new in-service training programs were recently added for school teachers, principals and administrators of high schools, as noted by professor Mawei, a recently retired senior professor. Dean Hengtang pointed out the strand of new teacher education courses at YNU would never have come into being if it were not for the implementation of the national reform. Still, some faculty members viewed this strategy as insufficient to enhance student learning in teacher education, and most interviewees saw it as a political tactic the top management adopted for the narrow purpose of promoting the status of the CES, rather than fulfilling the lofty goal of improving the quality of teacher education as outlined in the national policy.

\section{Restructuring academic departments for teacher education}

Early in 1992, YNU was authorized by the PBE to establish the School of Adult Education, which was the first of its kind in Yangtze province. It was also the university's first attempt to reorganize academic departments for teacher education since the 1990s. In the year of 2002, YNU underwent a radical reorganization of its academic departments. In all, seven colleges were established to adapt to the new demands arising from the radically changing society.

As introduced earlier, the CES was founded in the year 2000, by merging the Department of Educational Technology, the Institute of Higher Education and the Department of Educational Science. The new CES was being established to accommodate all the programs related to teacher education on campus, including the programs of subject-based teaching theories from each department of the campus. Most participants of this study, such as department chair Anping and professors Ningdong, Ouying and Peishi, saw the establishment of the CES as an optimization of strengths (qiangqiang lianhe) intended to generate a new "super strength" to improve the quality of teacher education at YNU. The restructuring of academic departments for teacher education was adopted by YNU as a rational way of maximizing academic strengths in order to implement the national reform.

\section{CHALLENGES IN THE POLICY IMPLEMENTATION}

The national initiatives of teacher education reform have been in effect for more than a decade on the campus of YNU and have brought about remarkable institutional transformations, which casted two major types of challenge over the implementation of the national reform, i.e., the contextually less amenable and the institutionally remediable. 
With the new mission, YNU's identity crisis has been contextually less amenable, in terms of the overriding influences of other nationwide policies, such as the expansion of higher education and the new curriculum reform for basic education. After the radical expansion of enrollment since the late 1990s, teacher education programs have been incapable of accommodating the large number of students or meeting the needs for socioeconomic development in Yangtze province. Therefore, YNU had to open new programs, e.g., non-teacher education programs. Professor Mawei was a retired senior professor in history of education. He noted that the ambiguity of teacher education identity was to be traced to the radical expansion of student enrollment in higher education:

We have to recruit students [for survival], so we could not limit student admission to teacher education. Like our college, teacher education students are only one-third, all the rest are non-teacher education students. Our identity is ambiguous now, the label we have is a normal university, but in fact we are no longer focusing just on teacher education.

While some interviewees deemed this change as unavoidable, Professor Peishi was very critical about the trend. He held that the ambiguity in YNU's identity had led to conditions challenging the legitimacy and status of teacher education. That is, teacher education as the traditional focus and strength of YNU was being undermined. Department chair Beihua expressed his criticism in the following way:

We are a normal university, right? Most of our students should be studying in teacher education programs for [our goals are to] prepare prospective teachers. But now our non-teacher education programs do not prepare teachers, and students in these programs are more than half of the total students registered.

Along with this challenge comes with the observed decline of YNU's academic status. Department chair Caifei compared YNU with other prestigious universities in the province from four aspects, i.e., public funding, leadership and administration, academic strengths, and campus location, and worried that YNU may have lagged behind others in all of the four. Director Gangyang added that the decline in the quality of undergraduate teaching explained why YNU had lagged behind:

The biggest contribution probably is the decline of undergraduate teaching quality.... It may be the radical expansion of recruitment, the low quality of the new students, the decline of investment in teacher workforce, etc. Thus, the whole social status [of YNU] is declining somewhat. The indicators of decline can be explained by some operational statistics, I think.

Although being institutionally possible, the effectiveness of the strategies YNU adopted for institutional transformations has given rise to wide doubt. For instance, professor Peishi shared his concerns about how the above strategies were severely mitigated by the political tensions and adverse factors in the implementation process. In his view, there were many: the overemphasis on quantifiable measurements to evaluate teachers' work; the radical expansion of student enrollment since the late 1990s; the decline in quality of the newly admitted students and the implementation of the national reform as more of a formality than genuine change.

\section{POLICY IMPLICATIONS FOR TEACHER EDUCATION REFORM}

Based on the above findings and discussions, key policy implications can be further 
raised from the YNU case of institutional transformations, with the examination of the two types of challenges.

\section{The Success of Policy Implementation Relies on Contextual Factors}

The success or failure of a public policy is commonly studied by examining the consistency between policy goals and outcomes (Van Meter \& Van Horn, 1975, p. 459). In addition, in their view, the higher the goal consensus is, the larger the amount of change (outcomes of policy) will be, and vice versa. When this study tried to reveal how the institutional goals of YNU were developed, it was surprising to find that the institutional goals had at least deviated somewhat from the national reform of teacher education. Conversely, the mission of YNU became ambiguous in terms of its original identity for teacher education.

The ambiguity of the university mission had a negative impact on the implementation of the national reform. For example, most participants held negative perceptions on the change of their institutional identity. They were critical of the fact that teacher education had traditionally been the featured strength at YNU, but now it was neglected. Many interviewees observed that in recent years, the educational skills of graduates had not even been competitive with those from less prestigious normal universities. They also witnessed the drop in institutional social status and public image of YNU. To a certain extent, the ambiguous policy goals hindered the implementation of the national policy at YNU.

In addition, many participants complained that the leaders of YNU did not fully recognize the importance of teacher education reform. The implementation of the national reform therefore proceeded at a snail's pace at the institutional level. An example was that the university had planned for a new College of Teacher Education (CTE) for several years but continued to await an official decision. As reported by many interviewees, the lack of policy recognition by key implementers greatly contributed to the unsatisfactory outcomes of the implementation of the national policy at YNU.

These have appeared to be reasons that can explain the dilemmas in YNU's institutional implementation of the national initiatives. But underneath the surface, the wider contextual factors, such as the national expansion of higher education and the new curriculum reform for basic education, played a significant and determinant role in limiting the scope of the changes expected from both policymakers and implementers in teacher education institutions, something which could not be simply and accurately anticipated or calculated from the rational framework.

\section{Authentic Evaluation Ensures Policy Implementation}

Evaluation is widely accepted as a rational and crucial step in the process of public policy. Browne and Wildavsky (1983) believed that "evaluation is a necessary component of program development and implementation," and that evaluation "can contribute to a continuing refinement in comprehension of the reasons why programs and policies do or do not work" (Browne \& Wildavsky, 1983, p. 182; p. 201).

Three major forms of evaluation of the implementation of the national reform were found at YNU: The university official evaluation system, the university regular or periodic evaluations on specific job performance, and the ad hoc evaluations conducted by the PBE. The first kind of evaluation was criticized by some participants as "a waste" because of its formality. The second one was blamed by some interviewees for putting additional job pressure on teachers. There was much criticism of the third one too, since it involved a lot of formalism and falsification. All of the three approaches to evaluation could be termed 
"pseudo-evaluations" (Dunn, 1981, p. 343), rather than "true evaluation" (Stufflebeam \& Webster, 1981, p. 71). From the rational framework, the second implication for policy implementation is that evaluation is a controllable and amenable step which can be improved by involving independent, third party participants to ensure effective measures.

\section{LIMITATIONS OF THIS STUDY}

Obviously the rational framework is not sufficient to answer why the intended outcomes were not strictly consistent with the policy goals and requirements as originally planned. In addition, the rational framework ignored political conflicts, e.g., conflict of interest between different stakeholders (Baldridge, Curtis, Ecker \& Riley, 1977) and is often criticized as "more an ideal than an actual description of how people act" (Baldridge, 1977). Alternative frameworks, e.g., political, organizational, normative or critical perspectives are needed for a more comprehensive examination of the dynamic, complex process of China's national initiatives and their impact on TEIs' institutional transformations. Multiple perspectives are therefore of great help to unearth "aspects and intricacies of policy that would be easily missed with a single lens look" (Malen \& Knapp, 1997).

Additionally, this study adopted a single-case design and purposefully selected an information-rich case to look for an in-depth explanation of the institutional transformations of China's national reform on teacher education. A single-case design is vulnerable by nature, however, and might be a limited case, possibly not representative at all. In other words, it provides a weak basis for its findings to be transferred to other settings. To minimize the possibilities of misrepresentation, a multiple-case design is desirable for future research. As Herriott and Firestone (1983) argued, the multiple-case design enhances the ability to generalize findings while preserving in-depth description, and is often considered more compelling, and the overall study is therefore regarded as being more robust (Yin, 2009).

Lastly, TEIs are not limited to provincial normal universities in China, but cover a large range of higher education institutions such as key national normal universities, key provincial normal universities, and junior normal colleges. Although key provincial normal universities are the largest base for teacher education in China, and the findings of the typical case purposefully selected by this study can be applied to other settings, a multiple-case design consisting of all three types of TEIs would greatly extend the understanding of teacher education reform in China.

\section{CONCLUSION}

When the rational framework is applied, China's quest for world-class teachers through the reform of teacher education can be viewed as rational collective behavior, in terms of policy initiation and formation as well as the implementation process and evaluation. In the case of YNU's institutional transformations, rational collective policy actions were evidently observed. Specifically, it was means-ends driven and followed goal directed principles. There was a cause and effect link between the theories of action and the stated outcomes. Policy was delivered in efficient ways such as the regular official policy propaganda. The implementation was designed in stages in a linearly advanced policy flow employing the most effective communication form available. Efforts were made to optimize the goals and to adopt alternative strategies for substantial problem resolution. There was a persistent adherence to scientific evaluations. Additionally, the implementation of the national policy has been promising for the institutional transformations taking place at YNU. The 
experiences from YNU were rooted in Chinese socio-cultural context, but may be applicable to other societal settings with careful considerations of local contexts.

There are multiple challenges arising from YNU's institutional changes in the process of the policy implementation, as well as some dimensions that are unexplainable by a rational lens, such as the overriding effects brought about by the nationwide expansion of higher education and the new curriculum reform for basic education. Further studies are desirable to examine the phenomenon in a more balanced way with an alternative research design. Again, these lessons are also valuable for policymakers in other contexts to reflect.

Nevertheless, the findings of this study are quite transferable with a theoretical sampling strategy, as they are based on the typical case of teacher education institution in China. Through the comprehensive investigation of how this typical TEI implemented China's national initiatives of teacher education since the 1990s, it can be concluded that China has systematically moved to a new stage of teacher professionalism and development with strenuous endeavors over recent decades. In this process, a Chinese model of teacher education reform is observable with rational thinking and logic, while priority of development is given to the excellent and steady provision of teachers by TEIs in meeting challenges of teachers' new identities and roles in a radically changing social context. Along with its rising status, in terms of excellence in educational performance and students' academic achievement, as shown in PISA 2009, China provides an alternative model of building a world-class teaching force and it is likely to contribute to the international community with multiple implications in the age of globalization. 


\section{REFERENCES}

Allison, G. T., \& Zelikow, P. D. (1999). Essence of decision: Explaining the Cuban missile crisis $\left(2^{\text {nd }}\right.$ ed.). New York: Longman.

Aronowitz, S., \& Giroux, H. A. (1993). Education still under siege (2 ${ }^{\text {nd }}$ Ed.). Westport, CT: Bergin \& Garvey.

Ashmore, R. A., \& Cao, Z. (1997). Teacher education in the People's Republic of China. Bloomington, IN: Phi Delta Kappa Educational Foundation.

Baldridge, J. V. (1977). Power and conflict in the university. New York: John Wiley \& Sons.

Baldridge, J. V., Curtis, D. V., Ecker, G. P., \& Riley, G. L. (1977). Alternative models of governance in higher education. In G. L. Riley \& J. V. Baldridge (Eds.), Governing academic organizations: New problems new perspectives (2-25). Berkeley, CA: McCutchen.

Browne, A., \& Wildavsky, A. (1983). What should evaluation mean? In J. L. Pressman \& A. Wildavsky (Eds.), Implementation: How great expectations in Washington are dashed in Oakland; or, why it's amazing that federal programs work at all, this being a saga of the economic development administration as told by two sympathetic observers who seek to build morals on a foundation of ruined hopes ( $2^{\text {nd }} \mathrm{Ed}$.) (pp. 181-205). Berkeley: University of California Press.

Dooley, K. (2001). Re-envisioning teacher preparation: Lessons from China. Journal of Education for Teaching, 27(3), 241-251.

Dunn, W. N. (1981). Public policy analysis: An introduction. Englewood Cliffs, NJ: Prentice Hall.

Elmore, R. F. (1978). Organizational models of social program implementation. Public Policy, 26(2): 185-228.

Fowler, F. C. (2013). Policy studies for educational leaders: An introduction (4 ${ }^{\text {th }}$ Ed.). Boston: Pearson.

Hayhoe. R. (2002). Teacher education and the university: A comparative analysis with implications for Hong Kong, Teaching Education, 13 (1), 5-23.

Hayhoe, R., \& Li, J. (2010). The idea of a normal university in the $21^{\text {st }}$ century. Frontiers of Education in China, 5 (1), 74-103.

Hayhoe, R., Li, J., Lin, J., \& Zha, Q. (2011). Portraits of 21st century Chinese universities: In the move to mass higher education. Dordrecht \& HK: Springer/CERC.

Herriott, R. E., \& Firestone, W. A. (1983). Multisite qualitative policy research: Optimizing description and generalizability. Educational Researcher, 12(2): 14-19.

Jenkins, W. I. (1978). Policy analysis: A political and organisational perspective. London: M. Robertson.

Leung, J., \& Xu, H. (2000). People's Republic of China. In P. Morris \& J. Williamson (Eds.), Teacher education in the Asia-Pacific region: A comparative study (pp. 175-197), New York and London: Falmer Press.

Li, D. F. (1999). Modernization and teacher education in China. Teaching and Teacher Education, 15, 179-192. 
Li, J. (2013, Feb. 7). Jianshi jiaoshi jiaoyu de zhongguo moshi [An examination of the Chinese model of teacher education]. Shehui Kexue Bao [Social Sciences Weekly]. No. 1349, 5. Retrieved May 20, 2013 from: http://www.shekebao.com.cn/shekebao/2012skb/xs/userobject1ai5359.html

$\mathrm{Li}, \mathrm{J}$. (2012). The Chinese model of teacher education: Retrospect and prospects over a century. Frontiers of Education in China, 7(3): 417-442.

Li, M. (2010). From teacher-education university to comprehensive university: Case studies of East China Normal University, Southwest University and Yanbian University. Frontiers of Education in China, 5 (4), 507-530.

Lin, Q., \& Xun, Y. (2001). The institutional and policy development of teacher education in China. Asia-Pacific Journal of Teacher Education \& Development, 4 (2), 5-23.

Lindblom, C. E. (1959, Spring). The science of muddling through. Public Administration Review, 19 (2), 79-88.

Ma, Q. R. (2000). Shanghai shifan jiaoyu gaige de xinqushi [The new trends of teacher education reform in Shanghai]. In B. Y. Lu (Ed.), Yitihua: Shifan jiaoyu gaige de sikao yu shijian [Amalgamation: Thought and practice of teacher education reform] (pp. 99-107). Shanghai: East China Normal University Press.

Malen, B., \& Knapp, M. (1997). Rethinking the multiple perspectives approach to education policy analysis: implications for policy-practice connections. Journal of Education Policy, 12 (5), 419-445.

OECD. (2012). Strong Performers and Successful Reformers in Education: Shanghai. Retrieved September 28, 2012 from the OECD Web Page: http://www.pearsonfoundation.org/oecd/china.html

OECD. (2010). PISA 2009 results: What students know and can do-Student performance in reading, mathematics and science (Vol. I). Retrieved September 28, 2012 from the OECD Web Page: http://dx.doi.org/10.1787/9789264091450-en

Paine, L. (1992). Teaching and modernization in contemporary China. In R. Hayhoe (Ed.), Education and modernization: The Chinese experience (pp. 183-209). New York: Pergamon Press.

Patton, M. Q. (2002). Qualitative research and evaluation methods ( $3^{\text {rd }}$ Ed.). Thousand Oaks, CA: Sage.

Shen, A. P. (1994). Teacher education and national development in China. Journal of Education, 176 (2), pp. 57-71.

Stufflebeam, D. L., \& Webster, W. J. (1981). An analysis of alternative approaches to evaluation. Evaluation Studies Review Annual, 6, 70-85.

The Ministry of Education. (2004, February 10). 2003-2007 Jiaoyu zhengxing xingdong jihua [The rejuvenation action plan for education 2003-2007]. Retrieved Feb. 12, 2013, from the China's Central People's Government Web Site: http://www.gov.cn/zwgk/200508/12/content_21704.htm

The State Council. (2012, Aug. 20). Guanyu jiaqiang jiaoshi duiwu jianshe de yijian [The Opinion on the Enhancement of the Teaching Workforce]. Retrieved Feb. 12, 2013, from the China's Central People's Government Web Site: http://www.gov.cn/zwgk/201209/07/content_2218778.htm 
Van Meter, D. S., \& Van Horn, C. E. (1975). The policy implementation process: A conceptual framework. Administration and Society, 6 (4), 445-488.

Ye, L. (2000). Zai xuexiao gaige shijianzhong zaojiu xinxing jiaoshi: Mianxiang ershiyi shiji xinjichu jiaoyu tansuo xing yanjiu tigong de qishi yu jingyan [Nurturing new teachers through the practice of school reform: Reflections and experiences from the Explorative research on New Basic Education for $21^{\text {st }}$ century]. Journal of the Chinese Society of Education, 4, 58-62.

Yin, R. K. (2009). Case study research: Design and methods ( $4^{\text {rd }}$ ed.). Thousand Oaks, CA: Sage.

Zhu, X. D. (2001). Guowai jiaoshi jiaoyu moshi de zhuanxing yanjiu [Research on the transformation of the models of the teacher's education abroad]. Studies in Foreign Education, 28 (5), 52-58. 